\title{
sciendo
}

CIVIL AND ENVIRONMENTAL ENGINEERING REPORTS

E-ISSN 2450-8594

CEER 2021; 31 (2): 0015-0029

DOI: $10.2478 /$ ceer-2021-0017

Original Research Article

\section{MAINTENANCE STRATEGIES, PERIODIC RENOVATIONS AND BUILDING MODERNISATION IN THE ASPECT OF THE CRITERION OF THE WHOLE LIFE COSTS}

\author{
Apolonia PRZESMYCKA ${ }^{1}$, Damian WIECZOREK ${ }^{2}$ \\ Cracow University of Technology, Faculty of Civil Engineering, Poland
}

\begin{abstract}
The article deals with the issues of building exploitation and maintenance and focuses on the characteristics of the maintenance strategies mentioned in the ISO 15686-5:2017 Buildings and constructed assets - Service life planning - Part 5: Life-cycle costing. The article describes all three strategies recommended by the ISO standard (preventive, corrective and deferred maintenance). The purpose of the article is to conduct whole life costs analysis of three variants of modernisations, renovations and maintenance strategies for a selected building. The methods of economic efficiency assessment were used, such as net present value (NPV) method and internal rate of return (IRR) method.
\end{abstract}

Keywords: maintenance strategies, periodical repairs, upgrades, life cycle, whole life costs, net present value, internal rate of return

\section{INTRODUCTION}

Nowadays, along with the global technological progress, the perception of the world and directions of development are changing. These, in turn, are increasingly

1 Graduate of the Cracow University of Technology, Faculty of Civil Engineering

2 Corresponding author: Cracow University of Technology, Faculty of Civil Engineering, Warszawska st. 24, 31-155 Cracow, e-mail: dwieczorek@L7.pk.edu.pl 
focused on sustainable development and the rational and prudent disposal of resources $[12,13]$. This trend is reflected in every area of modern life and is closely related to the changing needs and expectations of society. There is an increase in ecological, economic and social awareness, as well as a gradual change in standards aimed at sustainable activities. This phenomenon also applies to the construction industry, which is pointed out by the authors of the following publications $[2,3,7,8,11,12]$. In construction industry, the approach to residential and commercial office buildings is changing dynamically and is becoming more and more comprehensive $[9,12]$. Particular attention is paid to the estimation of life cycle costs (LCC) for each phase of the life cycle (design, completion, exploitation and decommissioning) taking into account all aspects related to the durability. This is confirmed by numerous scientific publications in the field of national (Polish) and world literature [4, 7, 12, 13].

The purpose of the article is to discuss the issues of building exploitation and maintenance, with particular emphasis on the maintenance strategies proposed by ISO 15686-5:2017 Buildings and constructed assets - Service life planning - Part 5: Life-cycle costing [5]. The authors also conducted whole life costs (WLC) analysis of three variants of modernisations, renovations and maintenance strategies for a selected building located in Cracow. For this purpose, methods of economic efficiency assessment, such as net present value (NPV) method and internal rate of return (IRR) method were used.

\section{EXPLOITATION AND MAINTENANCE}

Building exploitation is defined as a subset of actions that are related with a building performing required functions, what means building usage as it is intended, while building maintenance is defined as subset of activities related to enabling the building to perform the required functions, including necessary adaptation to changes in external conditions.

When presenting the definitions of maintenance and exploitation, it should also be specified what the exploitation life is, how it is understood. The period of exploitation should be defined by the time starting from the structure execution, until the useable features reach the minimum permissible level [16]. The designed durability of the structure and the use of appropriate renovation or maintenance works during the operation of the building may affect the change in the length of this period. The relationship between usefulness and the service life period is presented in the graph in Fig. 1. 


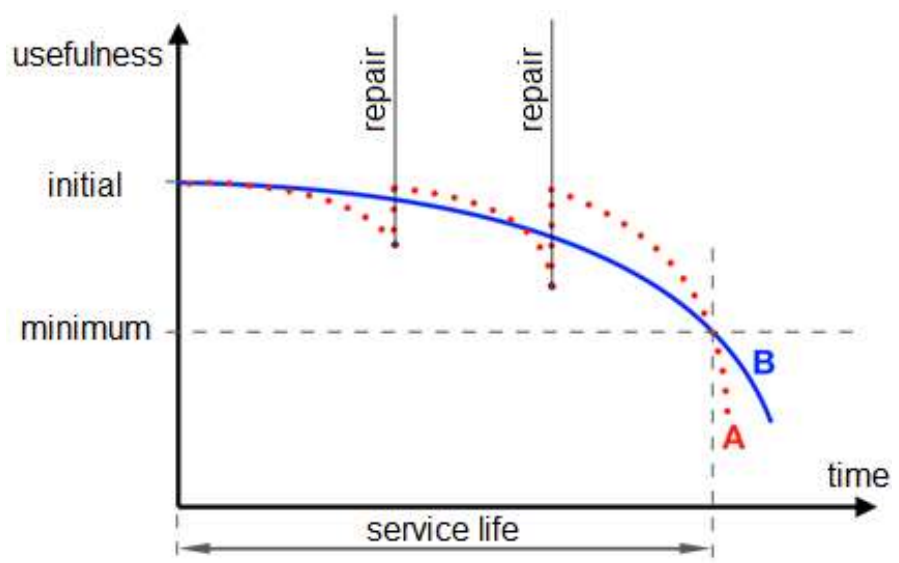

Fig. 1. The relationship between usefulness and the service life period

The dotted line (A) on the graph shows behaviour of usefulness features over time for an object subjected to cyclical repairs without indicating the high durability of the materials. The solid line (B), on the other hand, describes an object with high durability. Thanks to the graph, it should be observed that it is possible to extend the life of the object through repeated repair and maintenance work. As the external conditions change, the building's ability to perform the required functions is reduced and appears a necessity to adapt to the changes. Hence it can be concluded that a building, like a machine, requires compliance with proper use, maintenance and repair in a timely manner [10]. The ignorance of these observations leads to a reduction in usability value, technical value and thus durability. To prevent such a scenario, several maintenance strategies should be put together in order to select the most suitable solutions for the analysed building. The maintenance strategy is a kind of scenario presenting the arrangement of potential events. Describing more precisely, this scenario is a system of events related to a logical, generally chronological sequence. Analysed are the events that may occur and those which are significant for the subject for which the scenario is prepared, within the specified time and certain relationships (formal and legal, cause and effect, consequences in time) related in such a way that the estimation of the entire system of events is based on hypotheses resulting from the form and structure of these relationships [18].

Many examples of maintenance strategies can be found in the literature, but, when carefully analysed, three leading types of strategies can be clearly distinguished. The whole set of factors affecting the building and the needs specified by the user, have an influence on the most suitable strategy selection. Users goals determine the levels of maintenance and, as a consequence, can help in the proper selection of the maintenance strategy for the considered building. However, it should be 
kept in mind that over time there is a risk of unpredictable events that may affect the needs, goals and behaviour of users. Table 1 put together the maintenance levels, which are a kind of introduction to the scenarios further described.

Table 1. Maintenance levels

\begin{tabular}{|c|c|l|}
\hline Level & Description & \multicolumn{1}{|c|}{ Range } \\
\hline 1 & Ad hoc repairs & $\begin{array}{l}\text { Solutions focused on the elimination of damage } \\
\text { and restoring the ability of the element to } \\
\text { perform the relevant assumed functions }\end{array}$ \\
\hline 2 & Planned repairs & $\begin{array}{l}\text { Maintenance work planned, carried out in } \\
\text { accordance with the prepared schedule, } \\
\text { characterised by a specific range of work and } \\
\text { periodicity }\end{array}$ \\
\hline 3 & $\begin{array}{l}\text { Repairs resulting from the } \\
\text { conditions of exploitation }\end{array}$ & $\begin{array}{l}\text { Maintenance consisting of specific work } \\
\text { specified on the basis of research and actual } \\
\text { observation of the object }\end{array}$ \\
\hline
\end{tabular}

Description of maintenance strategies can be also found in ISO 15686-5:2017 Buildings and constructed assets - Service life planning - Part 5: Life-cycle costing [5]. The ISO standard provides three types of maintenance:

- Preventive maintenance depends on anticipation and planning the extent of repair work needed,

- Corrective maintenance relay on monitoring the facility and making repairs which react to failure or deterioration of the facility,

- Deferred maintenance is associated with the repair of the element only when necessary, usually connected with cost consequences.

\section{ECONOMIC ASSESSMENT METHODS}

\subsection{NPV method}

The net present value method is one of the investments economic assessment methods. This method is based on comparison of the expected streams of inflows generated during the operation of the investment with the outflows over a period of time. The most important feature of this method is the relationship between obtained income and involved funds.

The time of spent expenditures is often different from the time the income is received. Therefore, for these streams to be comparable, they should be updated discounted. While, the net present value (NPV) should be estimated as the difference between the sum of discounted net cash flows achieved during the exploitation of the project and the sum of investment outlays discounted for the same period [1]. Within carried out analyses, the NPV value was obtained by 
discounting the difference in inflows and outflows separately for each year over a period of 30 years at a constant discount rate.

$$
N P V=\sum_{n=0}^{T} \frac{C F_{n}}{(1+r)^{n}}
$$

$\mathrm{CF}$ - net cash flow - expected cash flow in the $\mathrm{n}$-th year

$\mathrm{n}$ - years of operation

$\mathrm{r}$ - discount rate

$\mathrm{T}$ - length of the period considered in years

The net present value calculations result can give both negative and positive values. If the calculated NPV is positive, it means that with the assumed interest rate of raising capital for the investment, it is a profitable investment. If the calculated NPV is zero, we can treat the investment as economically neutral. If the NPV is negative, the project profitability rate is lower than the rate of raising capital for the investment execution [6]. Consequently, negative NPV value means that the investment should be assessed as unprofitable.

A negative result may be the result of e.g. the assumed discount rate. Thus, the higher the discount rate used for the calculations, the lower the NPV will be. The relationship between the discount rate and the NPV value is presented in the graph in Fig. 2.

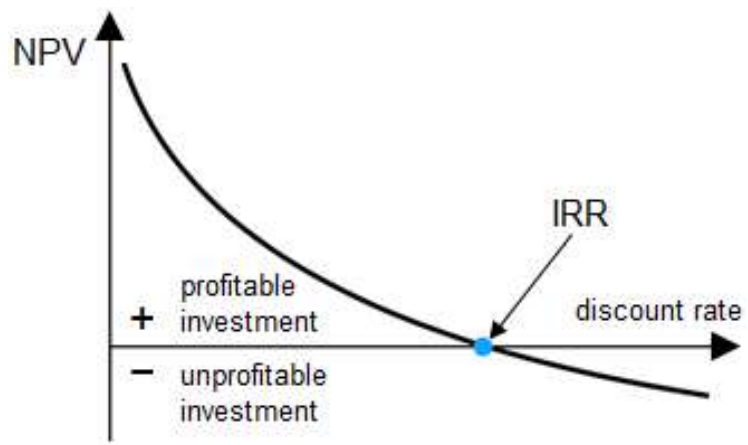

Fig. 2. The relationship between the discount rate and the NPV [1]

Discounting is understood as determining the current value of both current and future outflows and inflows. In theory, the interest rate is usually equal to the discount rate, but there is a certain relationship between them. Adopted discount rate reflects the real profit that can be achieved from the capital invested and should take into account the inflation rate and risk factor [3]. 
The discount rate can also be determined within the use of the base rate published by the European Commission. The base rate is the basis for calculating the reference rate. On the other hand, the reference rate is determined by adding to the base rate the appropriate margin specified in the European Commission communication. In force since June 1, 2020. and published on the website of the Office of Consumer Protection and Competition is a discount rate of $2.35 \%$. It is also possible to determine the real discount rate at which a real change in the amount of capital is a nominal change minus inflation relative to the rate of inflation. Such a relationship was presented by the American economist and statistician Irving Fisher in the form of a formula:

$$
r=\frac{1+R_{n o m}}{i+1}-1
$$

$\mathrm{r}$ - real discount rate

$\mathrm{R}_{\text {nom - nominal discount rate }}$

$\mathrm{i}$ - inflation rate

For the conducted analyses of the building's exploitation costs over the years, the discount value in the range of 6-10\% was adopted, relying on the values presented in publications $[3,12,13,14,15]$.

\subsection{IRR method}

The internal rate of return method, just like NPV, is a dynamic method that allows to assess investment on the basis of a cash flow stream. The IRR value is the discount rate at which the sum of the current value of cash flows is equal to zero [17]. This can be calculated using the formula:

$$
N P V=\sum_{n=0}^{T} \frac{C F_{n}}{(1+I R R)^{n}}
$$

$\mathrm{CF}$ - net cash flow - expected cash flow in the n-th year $\mathrm{n}$ - years of operation

$\mathrm{T}$ - length of the period considered in years

$\mathrm{NPV}=0$

In comparison of NPV with IRR, it should be marked that there was an exchange of data and unknowns in the formula. The discount rate that was specified in NPV, in this case is the value sought. Respectively, NPV was previously searched and within this formula is equal zero. The IRR rate is the profitability of the project compared with the cost of capital (discount rate). When assessing investments, 
using the IRR method, only ventures for which profitability (IRR) is equal to or higher than capital costs are accepted.

Calculating the IRR value is relatively difficult and absorbing. This causes the fact that beside calculating cash flow values, there should also be found the discount rate for which the NPV will be zero. Hence, for NPV, positive and negative values close to zero should be determined. In order to find the internal rate of return, the formula below:

$$
I R R=r^{(+)}+\frac{N P V_{(+)}\left(r_{(-)}-r_{(+)}\right)}{N P V_{(+)}-N P V_{(-)}}
$$

Fig. 3 shows the interpolation of the IRR value calculated by the formula (3.4). The assumption here is that the course of the curve presented in Fig. 2 is simply linear (locally on the section between $\mathrm{r}+$ and $\mathrm{r}-$ ).

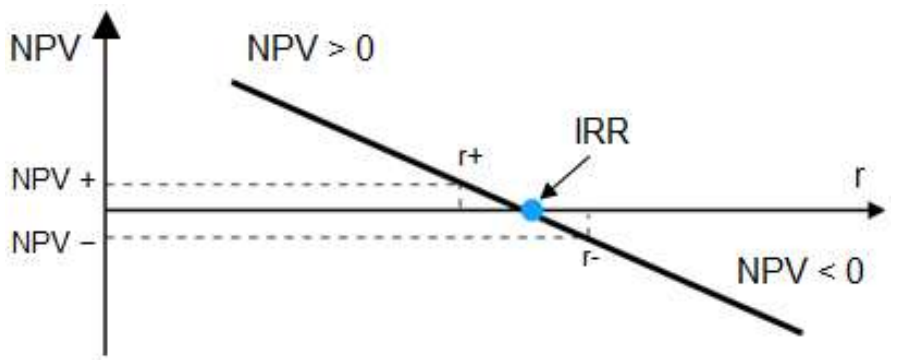

Fig. 3. Internal Rate of Return

\section{WHOLE LIFE COSTS ANALYSIS. VARIANTS OF MODERNISATIONS, RENOVATIONS AND MAINTENANCE STRATEGIES OF A BUILDING}

\subsection{Operating costs}

The costs incurred during the exploitation of the building can be divided into two groups - the costs associated with the running maintenance of the facility, which can be called permanent, and the costs associated with renovations, repairs and modernizations, which are incurred over time. In the paper all expenditures are treated as negative values and all incomes as positive values. Operating costs depend on assumed time periods. Following costs were considered: running costs - standard, costs of partial repairs incurred every 5 years, costs of more vast repairs incurred every 10 years, and costs of major repairs expected every 20 years on average. Due to the fact that the analysed building has already been in service for 20 years, it requires immediate repairs that prevent serious malfunctions, 
damages. These costs appear at the beginning and have been included in every variant of the carried out analyses.

The considered building has defects that may be hazardous to the material of the structure, reduce its durability and should be removed immediately. Defects that require special and urgent attention are moisture ingress and mold foci.

In order to estimate the costs of modernization renovation works for individual calculation variants, prices were determined using the prices presented in Material Inventory Catalogues, Product Catalogues and manufacturers' offers. Examples of renovation works included in the scenarios are presented in Table 2.

Table 2. Selected examples of renovation works

\begin{tabular}{|c|c|c|}
\hline \multicolumn{3}{|c|}{ Selected renovation works - example costs } \\
\hline \multicolumn{3}{|c|}{ Shell } \\
\hline \multirow{2}{*}{ Elevation } & Thermal insulation & 20000,00 PLN \\
\hline & Painting & 3000,00 PLN \\
\hline \multirow{3}{*}{ Roof } & Top surface and thermal insulation exchange & 12000,00 PLN \\
\hline & Top surface exchange & 7000,00 PLN \\
\hline & Rain gutters and downspout exchange & 1500,00 PLN \\
\hline Cellar walls & $\begin{array}{l}\text { Execution of vertical hydroinsulation and building } \\
\text { drainage }\end{array}$ & 11000,00 PLN \\
\hline \multirow{3}{*}{ Openings } & Roof windows exchange & 10000,00 PLN \\
\hline & Doors exchange & 6000,00 PLN \\
\hline & Roof windows' painting with protective coating & 300,00 PLN \\
\hline \multicolumn{3}{|c|}{$\begin{array}{c}\text { Installations } \\
\end{array}$} \\
\hline \multirow[b]{2}{*}{ Electrical installation } & Installation exchange & 15000,00 PLN \\
\hline & $\begin{array}{l}\text { Replacement of electrical installation equipment - } \\
\text { electric furnace, alarm }\end{array}$ & 20000,00 PLN \\
\hline Heating installation & Installation maintenance & 4000,00 PLN \\
\hline $\begin{array}{l}\text { Water heating } \\
\text { installation }\end{array}$ & Installation maintenance & 2000,00 PLN \\
\hline \multirow{3}{*}{ Ventilation } & Hygrostered diffusers - windows & 1200,00 PLN \\
\hline & Ventilation exhaust fan & 3000,00 PLN \\
\hline & Mechanical ventilation & 12000,00 PLN \\
\hline Photovoltaics panels & Taking advantage of grants for PV installation & 27000,00 PLN \\
\hline \multicolumn{3}{|c|}{ Building interior } \\
\hline \multirow{2}{*}{ Stair } & Wooden, wider stair structure exchange & 9000,00 PLN \\
\hline & Non-slip lining for floating stairs & 700,00 PLN \\
\hline \multirow{2}{*}{ Entrance } & Vestibule renovation & 700,00 PLN \\
\hline & Vestibule painting & 300,00 PLN \\
\hline \multirow{4}{*}{ Level $1 \& 2$} & Painting & $8000,00 \mathrm{PLN}$ \\
\hline & Parquet scraping & $1500,00 \mathrm{PLN}$ \\
\hline & Floor replacement & 8000,00 PLN \\
\hline & Furnishings / equipment replacement & 20000,00 PLN \\
\hline \multirow{2}{*}{ Level -1 } & Painting & 3000,00 PLN \\
\hline & Floor replacement & 3000,00 PLN \\
\hline
\end{tabular}




\subsection{Variants characteristics}

\section{Variant I}

Variant I of the modernization takes into account the lowest expenditure on repairs and is conservative in nature. It preserves established building standard with reasonably planned expenses - not excessive. This scenario is focused on maintenance that has a tendency to be deferred so as not to generate unnecessary costs. It assumes repeatable repair of most faults till the end of life of element or material. Due to the fact that the building is going to be rented, it will require refreshing the rooms so that the owner can profit from it at a similar level year to year. Refreshment will be limited to painting and necessary minor repair works. The scenario also includes a certain amount devoted for renovations carried out once every 10 years. Renovations at such an interval are mainly provided for installations that require certain maintenance work so that the building can constantly fulfil its function.

All variants predict the need for a major renovation in year zero, which aims to adapt the building for rent and eliminate hazardous defects. The next major renovation is considered only after reaching the designed service life in order to postpone large expenses as much as possible. The end of the designed period could also be a point of withdrawal of the object, but such a scenario was not taken into account due to the decent condition of the building.

\section{Variant II}

Option II of the modernization is focused on the preventive maintenance scenario. Takes into account moderate costs for repairs and focuses on running repairs. It aims to maintain the appropriate standard of the object and does not allow for negligence that could limit day to day building usage or cause subsequent failures. This scenario focuses on constant monitoring the technical condition of the building to obtain a greater time horizon for organizing the necessary repairs. Scheduled inspections should facilitate expenditure control and accelerate fault detection. This option outlines a much more comprehensive approach to the maintenance of equipment and installations in the building. The variant assumes the replacement of basic elements, whose durability will be significantly reduced, so as not to allow for the "domino effect", in other words that one seemingly small fault does not generate another, which, as a consequence, could significantly deteriorate the building standard and create additional costs.

\section{Variant III}

Option III takes into account significantly high budget for initial modernizations, which will increase the building's standard and affect the reduction of annual operating costs, while enabling higher inflows than in previous variants. The 
scenario assumes installation of photovoltaics panels to reduce fees for the consumption of electricity.

In option III, major renovations were abandoned in favour of higher amounts for renovations carried out in a 10-year time interval. Such renovations are to include a wide range of renovation works aimed at maintenance of the installation, replacement of obsolete equipment and planned verification of the technical condition in order to identify potential defects. Option III presents the most extensive maintenance scenario and planned repairs. It assumes higher amounts of expenses but at the same time increases rental profits due to the increased standard of the facility. It considers condition based maintenance with a tendency to be preventive. This option fits most strongly in the concept of sustainable development, including energy-efficient solutions.

\subsection{Results discussion}

While assessing the economic efficiency of the presented scenarios several computational analyzes based on dynamic methods were carried out. After determining the exact costs of individual scenarios, their cash flows were verified, in order to check the difference between the predicted inflows and outflows in the considered period of time. The analysis shows that for each variant, the accumulated proceeds will cover the accumulated expenses after only 3 years. In addition, attention should be paid to the situation of accumulated cash flows after 30 years. After this period of time, in option I the cumulated expenses will constitute $52 \%$ of the cumulated inflows, in option II slightly less - $45 \%$, and in option III only $40 \%$.

The NPV method compares the streams of expected revenues generated in the operation process with the expenditure incurred for the implementation of renovation projects and condition based maintenance of the facility. It has been assumed that the rate of return required by the investor will be in the range of $6 \%$ $-10 \%$. As can be seen in the graphs in Fig. 4, each variant generates a positive NPV. NPV equals 194,588.61 PLN to 309,053.01 PLN for variant I (when $\mathrm{r}$ is $10 \%$ to $6 \%$, respectively), $307,233.16$ PLN to $484,453.39$ PLN for variant II and $458,007.34$ PLN to $714,664.76$ PLN for variant III. This means that the adopted scenarios are profitable and from the financial point of view each of them would be a beneficial solution for the investor. 
MAINTENANCE STRATEGIES, PERIODIC RENOVATIONS AND BUILDING

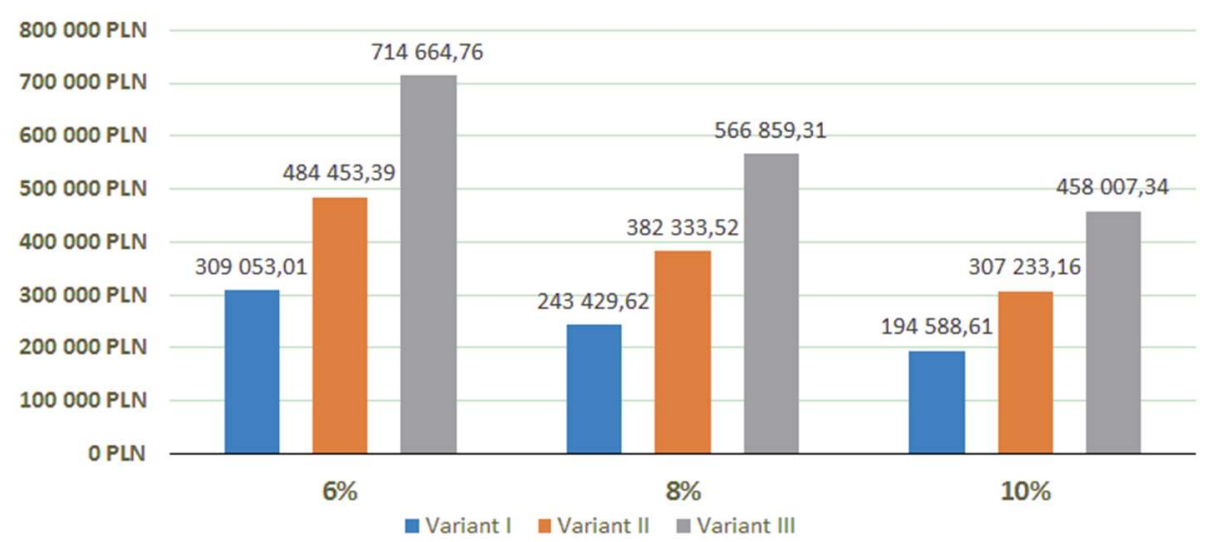

Fig. 4. NPV depending on discount rates

Fig. 5, on the example of Variant III, depicts the behavior of NPV values over the assumed period of exploitation, in dependence of different discount rates. The charts also show that each of the scenarios achieves a higher profit rate than the highest discount rate adopted for the calculations. Ultimately, each variant generates a relatively high surplus - in thousands of zlotys. The implementation of each of the variants will contribute to the investor's wealth increase.

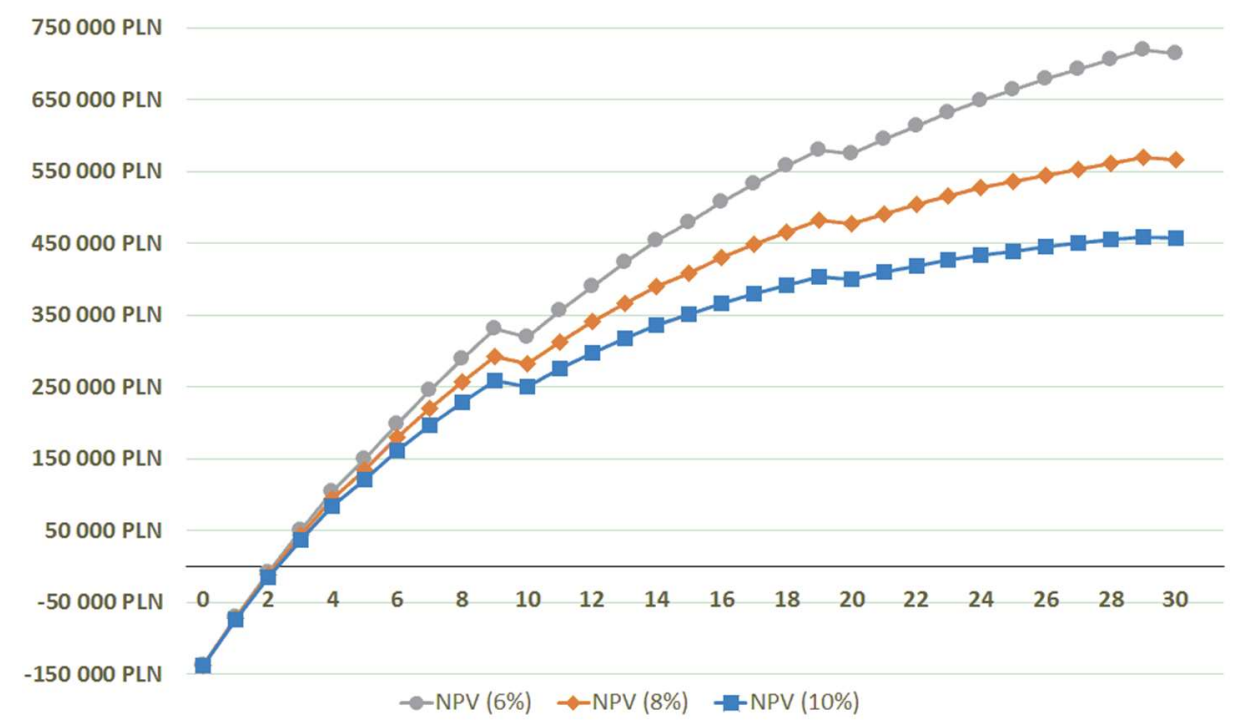

Fig. 5. NPV at n-th year of the assumed service life for Variant III

In addition, all options were assessed using the IRR method. The calculation of the internal rate of return accepts those investments whose value of the calculated IRR is greater than the required rate of return. The greater the difference between 
these values, the more profitable the option under consideration, and the higher the investor's profits. As can be seen in Fig. 6 IRR for each adopted scenario is at a very high level. IRR ranges $41 \%$ for variant I, $46 \%$ for variant II and $50 \%$ for variant III. The biggest difference between the IRR and the cost of capital can be seen in option III, which makes it the most profitable. However, each variant has significant differences, which allows you to consider all scenario options as safe. The relationship between the discount rate and the NPV value for selected variants is shown at Fig.6. This graph confirms the security guarantee for all variants. It says that even a very high discount rate could still ensure investment profitability. However, in reality very high discount rates do not occur. Moreover, this investment should take into account risk factors (e.g. failures, unintentional events) associated with the adopted scenarios, which were not included in the scope of the work and require further calculations and analyses.

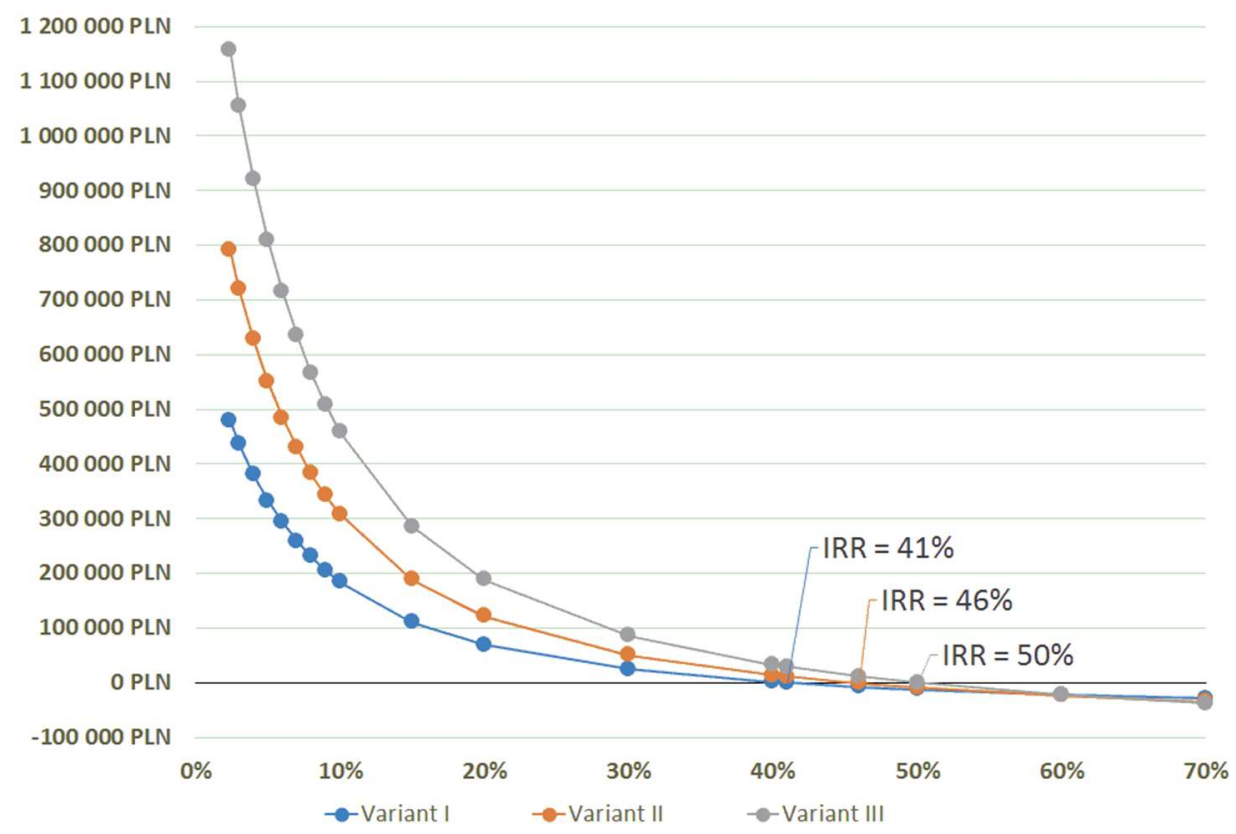

Fig.6. NPV and IRR values for all Variants

To sum up, each of the variants is beneficial for the investor and economically profitable. When analysing the selection of the best option, one should also take into account the chart below (Fig. 7), which shows a comparison of cumulative revenues (inflows) and expenses (outflows) for each variant. You can read from it that the differences in income generated by the building for certain variant are greater than expenses for renovations. Hence, it can be concluded that option III 
would guarantee the highest profits at slightly higher financial outlays than those assumed in variants I and II.

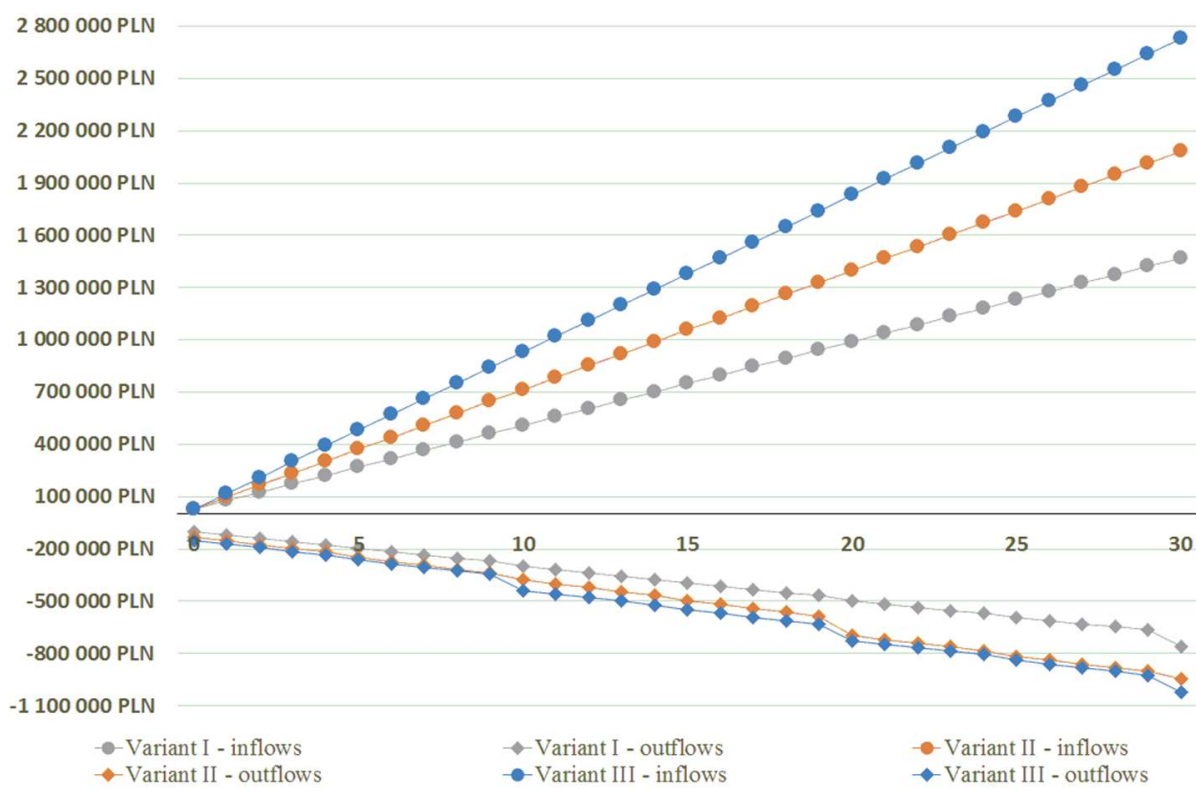

Fig.7. Cumulated inflows and outflows during the service life of the analysed building

\section{CONCLUSIONS}

The aim of the article was to discuss the issues of building exploitation and maintenance, with particular emphasis on the maintenance strategies proposed by ISO 15686-5:2017 [5]. The authors also conducted whole life costs analysis of three variants of modernisations, renovations and maintenance strategies for a selected building located in Cracow.

The obtained results show that for each scenario, the accumulated revenues (inflows) will cover the accumulated expenses (outflows) after only 3 years. In addition, the situation of accumulated cash flows after 30 years depicts that after this period of building life cycle, in variant I the cumulated outflows will constitute $52 \%$ of the cumulated inflows, in variant II slightly less - $45 \%$, and in variant III $-40 \%$. As can be seen in the graph in Fig. 4, each variant generates a positive NPV, but for variant III, NPV are the largest (458,007.34 PLN when $r$ is $10 \%, 566,859.31$ PLN when $\mathrm{r}$ is $8 \%$ and $714,664.76 \mathrm{PLN}$ when $\mathrm{r}$ is $6 \%$ ). IRR value for each adopted scenario is at a very high level. IRR equals $41 \%$ for variant I, $46 \%$ for variant II and $50 \%$ for variant III. Both NPV and IRR economic criteria indicate that the adopted scenarios are profitable and each of them would be a beneficial solution for the investor, with option III being the most profitable. 
Despite the fact that all three different scenarios propositions of building maintenance are beneficial, it should be pointed out that profitability increases with the use of more advanced modernizations, which allow the assumption of slightly higher profits due to the attractiveness of the object.

Moreover, it should be mentioned that variant III includes planning larger outlays for periodic repairs, what is more advantageous from the economic point of view than carrying out capital-intensive major repairs. Periodic repairs allow maintaining a high standard of a building, which during the period of service life may lead to a reduction in the expenditure devoted to renovations and help to maintain the expected level of usefulness of the analyzed building.

\section{REFERENCES}

1. Cieślik, R and Postuła, M 2016. Investment projects, financing, budgeting, effectiveness assessment (Projekty inwestycyjne finansowanie, budżetowanie, ocena efektywności). Warszawa: Difin S.A.

2. Drozd, W and Leśniak, A 2018. Ecological Wall Systems as an Element of Sustainable Development - Cost Issues. Sustainability 10(7), 2234. DOI: 10.3390/su10072234.

3. Dziadosz, A 2015. Model for estimating the whole life cost of a building (Model oszacowania łącznych kosztów cyklu życia obiektu). In: T. Kasprowicz (ed) Inżynieria Przedsięwzięć Budowlanych - Rekomendowane metody i techniki. Warszawa: PAN KILiW, IPB, 245-265.

4. Fregonara, E and Ferrando, D. G 2020. The Stochastic Annuity Method for Supporting Maintenance Costs Planning and Durability in the Construction Sector: A Simulation on a Building Component. Sustainability 12(7), 2909. DOI: $10.3390 /$ su12072909.

5. ISO 15686-5:2017 Buildings and constructed assets - Service life planning Part 5: Life-cycle costing.

6. Kietliński, W and Janowska, J 2015, Investment process in construction (Proces inwestycyjny $w$ budownictwie). Warszawa: Oficyna Wydawnicza Politechniki Warszawskiej.

7. Korentz, J and Nowogońska, B 2018. Assessment of the life cycle of masonry walls in residential buildings. MATEC Web of Conferences EDP Sciences, $3^{\text {rd }}$ Scientific Conference Environmental Challenges in Civil Engineering (ECCE 2018), Opole, Poland, April, 23-25, Vol. 174, 01025. DOI: 10.1051/matecconf/201817401025.

8. Leśniak, A, Plebankiewicz, E and Zima, K 2012. Cost calculation of building structures and building works in Polish conditions. Engineering Management Research 1(2), 72-81. DOI: 10.5539/emr.v1n2p72. 
9. Leśniak, A, Wieczorek, D and Górka, M 2020. Costs of facade systems execution. Archives of Civil Engineering 66(1), 81-95. DOI: $10.24425 /$ ace. 2020.131776 .

10. Linczowski C 1992. Durability, protection and operation of buildings (Trwałość, ochrona i eksploatacja budowli). Częstochowa: Wydawnictwo Politechniki Częstochowskiej.

11. Mrówczyńska, M, Łączak, A, Bazan-Krzywoszańska, A and Skiba, M 2018. Improving energy efficiency with the risk of investment of reference to urban development of Zielona Góra. Tehnicki Vjesnik-Technical Gazette 25(3), 916922. DOI: 10.17559/TV-20161212120336.

12. Plebankiewicz, E 2014. Directions efforts to reduce costs in the life cycle of municipal buildings (Kierunki działań zmierzających do obniżenia kosztów w cyklu życia budynków miejskich). In: A. Halicka (ed) Budownictwo na obszarach zurbanizowanych: Nauka, praktyka, perspektywy. Lublin: Wydawnictwo Politechniki Lubelskiej.

13. Plebankiewicz E, Biadała K and Wieczorek D 2015. Life cycle costs of built structures. In: E. Plebankiewicz (ed) Recent advances in Civil Engineering: Construction Management. Kraków: Wydawnictwo Politechniki Krakowskiej, 83-96.

14. Plebankiewicz, E, Zima, K and Wieczorek, D 2018. Life Cycle Equivalent Annual Cost (LCEAC) as a comparative indicator in the life cycle cost analysis of buildings with different lifetimes. MATEC Web of Conferences EDP Sciences, XXVII R-S-P Seminar, Theoretical Foundation of Civil Engineering (TFoCE 2018), Rostov-on-Don, Russia, September, 17-21, Vol. 196, 04079. DOI: $10.1051 /$ matecconf/201819604079.

15. Plebankiewicz, E, Meszek, W, Zima, K and Wieczorek, D 2020. Probabilistic and Fuzzy Approaches for Estimating the Life Cycle Costs of Buildings under Conditions of Exposure to Risk. Sustainability 12(1), 226. DOI: $10.3390 / \mathrm{su} 12010226$.

16. Ściślewski, Z 1995. Durability of buildings (Trwatość budowli). Kielce: Wydawnictwo Politechniki Świętokrzyskiej.

17. Wawrzyszuk, A 2004. A few critical remarks about the internal rate of return (IRR) (Kilka uwag krytycznych o wewnętrznej stopie zwrotu (IRR)). Annales Universitatis Mariae Curie-Sklodowska. Sectio H, Oeconomia 38, 371-384.

18. Zemke, J 2015. Reliability of forecasts, about alternative forecast construction instruments (Wiarygodność prognoz, o alternatywnych instrumentach konstrukcji prognoz). Ekonometria 4(50), 249-250. DOI: 10.15611/ekt.2015.4.16.

Editor received the manuscript: 02.08.2020 